\title{
PERLINDUNGAN HUKUM PEMBELI HAK ATAS TANAH BERDASARKAN PERJANJIAN PENGIKATAN JUAL BELI SECARA BERTINGKAT OLEH NOTARIS MENURUT PRINSIP-PRINSIP EKONOMI SYARIAH
}

\author{
Troy Permata Saputro \\ Chamim Tohari \\ Fakultas Hukum Universitas Brawijaya, \\ permata.troy@gmail.com
}

\begin{abstract}
The agreement of a transaction is a prelimenary agreement before the main agreement (AJB) done in front of the PPAT. PPJB often causes a problem when the right of the land is treated as a commodity by the seller and it is not registered its changes in Agrarian Office. The registration may be done after the right of the land is changed into the lastest buyer.

The approach of this research uses the approach of laws and the conceptual approach. The result of the analysis is concluded as the law protection of the latest buyer in accord with Government Regulations No. 24 of 1997 about the land registration, so that the Notary in maing PPJB has an obligation to pay attention to the principles of caution and the risks because of law concerning the document of the buyer.
\end{abstract}

Key words : Agreement of transaction; document of transaction; the right of the land and the building.

\section{PENDAHULUAN}

Perjanjian yang lahir berdasarkan interaksi satu orang atau lebih dengan satu orang lain atau lebih ini pasti memiliki hak dan kewajiban diantara mereka berupa hak dan kewajiban berupa pemenuhan suatu prestasi. Perjanjian harus ada kata sepakat diantara kedua belah pihak, karena perjanjian merupakan perbuatan hukum bersegi dua atau jamak. Sepakat dapat diartikan ketika perjanjian itu sudah memiliki akibat hukum, hal ini sesuai dalam Pasal 1320 Kitab Undang-Undang Hukum Perdata butir 1 (pertama) yang menyatakan sepakat merupakan syarat sahnya perjanjian.

Perikatan dapat lahir dari perjanjian maupun dari undang-undang, demikianlah rumusan Pasal 1233 KUH Perdata.Rumusan tersebut menunjukkan pada kita semua bahwa setiap kewajiban yang ada pada suatu perikatan dapat terwujud karena dua hal, pertama karena ditentukan demikian oleh undang-undang, dan kedua karena memang dikehendaki oleh para pihak dengan mengadakan atau membuat suatu perjanjian.Dengan demikian, setiap pihak yang membuat perjanjian dengan pihak lainnya secara sadar memang bermaksud untuk mengikatkan dirinya guna melaksanakan suatu kewajiban dalam lapangan harta kekayaan yang merupakan perikatan atau utang bagi dirinya terhadap lawan pihaknya dalam perjanjian tersebut. ${ }^{1}$

Tanah merupakan sarana yang sangat bernilai dalam sebuah pembangunan. Berdasarkan ketentuan Pasal 5 Undangundang Nomor 5 Tahun 1960 tentang Peraturan Dasar Pokok-Pokok Agraria sebagaimana dimuat di dalam Lembaran Negara Tahun 1960 Nomor 104 dan Penjelasan Umumnya dimuat di dalam Tambahan Lembaran Negara Republik Indonesia Nomor 2043 dijelaskan bahwa hukum tanah yang berlaku di Indonesia adalah berdasarkan Hukum Adat.

Menurut hukum adat dalam UUPA, jual beli tanah merupakan suatu perbuatan hukum pemindahan hak atas tanah dengan pembayaran harganya dilakukan secara tunai, artinya harga yang disetujui bersama

\footnotetext{
1 Widjaja Gunawan, Kartini Muljadi, Jual Beli (Jakarta: PT. Raja Grafindo Persada, 2003), hlm. 1.
} 
telah dibayar pada saat dilakukan jual beli. ${ }^{2}$ Tunai dalam hal ini bukan dalam arti harga tanah harus dibayar secara keseluruhan, tetapi juga bisa dibayar secara sebagian.Hal ini karena meskipun dibayar secara sebagian, tetapi menurut hukum hal ini dianggap sudah dibayar secara keseluruhan. Selanjutnya sisa pembayaran harga yang belum dibayar akan dianggap sebagai hutang piutang kepada pihak penjual. ${ }^{3}$ Selain bersifat tunai, jual beli tanah juga memiliki sifat dan ciri sebagai perbuatan yang terang dan riil. ${ }^{4}$ Terang adalah perbuatan jual beli tanah tersebut harus dilakukan di hadapan PPAT yang berwenang untuk membuat AJB. ${ }^{5}$ Sedangkan yang dimaksud dengan riil adalah menunjukkan secara nyata bahwa akta PPAT telah ditandatangani oleh kedua belah pihak.

Untuk menjamin kepastian, ketertiban, dan perlindungan hukum kepada masyarakat, khususnya pihak penjual dan pihak pembeli dalam membuat perjanjian jual beli dibutuhkan alat bukti tertulis yang bersifat autentik mengenai keadaan, peristiwa, atau perbuatan hukum yang diselenggarakan melalui jabatan tertentu dan bahwa notaris merupakan pejabat tertentu yang menjalankan profesi dalam pelayanan konsekuensi terhadap perjanjian yang dibuat oleh para pihak dapat menimbulkan cacatnya sebuah perjanjian apabila tidak dipenuhinya kata sepakat, maka "sepakat" mestinya merupakan syarat mutlak agar perjanjian itu sah. Pasal 16 ayat (1) huruf a disebutkan pula bahwa dalam menjalankan jabatannya, seorang notaris wajib untuk "bertindak amanah, jujur, seksama, mandiri, tidak berpihak dan menjaga kepentingan terkait dalam perbuatan hukum".Seorang

\footnotetext{
2 Boedi Harsono, Hukum Agraria Indonesia: Sejarah Pembentukan Undang-Undang Pokok Agraria, Isi dan Pelaksanaannya (Cetakan ke-7), (Jakarta, Universitas Trisakti, 2013), hlm. 29.

3 Effendi Perangin, Hukum Agraria Di Indonesia: Suatu Telaah Dari Sudut Pandang Praktisi Hukum, Cetakan Ke-3, (Jakarta, Rajawali, 1991), hlm. 1617.

${ }^{4}$ Boedi Harsono, Op.Cit, hlm. 193.

5 ibid, hlm. 28
}

notaris wajib untuk memberikan pelayanan sesuai dengan ketentuan dalam Undangundang jabatan notaris kecuali ada alasan untuk menolaknya. ${ }^{6}$

Kewenangan notaris yang utama adalah sebagaimana dimaksudkan di dalam ketentuan Pasal 15 ayat (1) Undang-Undang Republik Indonesia Nomor 30 Tahun 2014 tentang Jabatan Notaris yang diubah dengan Undang-undang Republik Indonesia Nomor 2 Tahun 2014 tentang Perubahan atas Undang-undang Republik Indonesia Nomor 30 Tahun 2004 tentang Jabatan Notaris (UUJN), yakni notaris berwenang membuat akta autentik tentang semua perbuatan, perjanjian, dan penetapan yang diharuskan oleh peraturan perundang-undangan dan/atau yang dikehendaki oleh yang berkepentingan untuk dinyatakan dalam akta autentik. Seorang notaris sebelum menentukan akta apa yang harus dibuat perlu pertimbangan hukum terlebih dahulu boleh atau tidaknya dibuatkan akta notaris untuk peristiwa hukum tersebut. Isi muatan akta notaris harus didasarkan pada unsurunsur perbuatan hukum yang dimaksudkan (para) kliennya, syarat-syarat sahnya dan ketentuan lain termasuk asas-asas hukum, teori hukum, logika hukum, doktrin, yurisprudensi, serta peraturan perundangundangan yang berlaku. Hal tersebut mengingat bahwa notaris harus dapat mempertanggungjawabkan akta yang telah dibuatnya. ${ }^{7}$ Dalam hal ini mempertanggung jawabkan akibat hukum pembuatan akta perjanjian jual beli yang dibuat secara bertingkat.

Sebagai pejabat umum, seorang notaris harus memegang teguh prinsip kehati-hatian, oleh sebab pertanggungjawaban seorang notaris terhadap akta yang dibuatnya adalah seumur hidup. Dalam membuat akta otentik notaris harus mendahulukan prinsip kehati-hatian utamanya akta mengenai

\footnotetext{
6 Wawan Setiawan, Sikap Profesionalisme Notaris Dalam Pembuatan Akta Otentik, (Jakarta, Media Notariat, 2004), hlm. 25.

${ }^{7}$ Herlien Budiono, Demikian Akta Ini, (Bandung, PT. Citra Aditya Bakti, 2018), hlm. 1.
} 
perjanjian, sebab akta mengenai perjanjian umumnya mempunyai konsekuensi hukum apabila terjadi wanprestasi (melanggar kesepakatan) oleh para pihak. Akta sebagai produk yang dibuat oleh notaris merupakan alat bukti yang sempurna demi kepastian hukum, akta yang dibuat oleh atau dihadapan pejabat harus dianggap benar dan mempunyai kekuatan hukum yang mengikat sebelum dibuktikan sebaliknya. Pada dasarnya sikap kehati-hatian notaris dalam menjalankan jabatannya berawal dari perbedaan dan ketidaksamaan kepentingan diantara para pihak. Dalam hal ini notaris sebagai pihak yang netral hanya membingkai dengan perangkat hukum bagi para pihak, sehingga tercapainya perjanjian dari sisi kepastian dan keadilan diantara para pihak terakomodasi melalui hubungan perjanjian yang berjalan secara seimbang.

Perjanjian Pengikatan Jual Beli kemudian selanjutnya akan disingkat PPJB merupakan perjanjian innominat disebut juga perjanjian tidak bernama karena tidak diatur dalam KUH Perdata. KUH Perdata Pasal 1457 menyebutkan "Jual beli adalah suatu persetujuan, dengan mana pihak yang satu mengikatkan dirinya untuk menyerahkan suatu hak kebendaan, dan pihak lain membayar sesuai harga yang diperjanjikan". Perjanjian pengikatan jual beli dan kuasa menjual yang dibuat berlandaskan Pasal 1338 KUH Perdata merupakan perjanjian yang secara sah berlaku sebagai undang-undang bagi mereka yang membuatnya, sehingga PPJB dan kuasa menjual bertujuan untuk mencegah terjadinya sengketa sejalan dengan keterkaitan antara Pasal 1457 KUH Perdata dalam rangka memenuhi kewajiban hukum para pihak dengan diterapkannya Pasal 1459 KUH Perdata wajib dilakukan penyerahan secara yuridis yang diatur dalam Pasal 616 dan Pasal 620 KUH Perdata menurut pasal tersebut penyerahan yuridis itu dilakukan juga di hadapan notaris. Penyerahan Yuridis (yuridische levering) dalam kaitannya obyeknya adalah tanah dan peralihan jual beli yang dilakukan sesuai dengan penelitian penulis yang harga jual belinya belum lunas atau obyek jual beli tersebut masih dalam proses lain maka lebih dahulu para pihak wajib membuat PPJB dan kuasa menjual dihadapan notaris, kemudian membuat Akta Jual Beli di hadapan PPAT dan didaftar di lembaga pendaftaran yang diperuntukkan untuk itu. Penyerahan Yuridis yang berkaitan dengan tanah maka dilakukan pendaftaran peralihan haknya di Kantor Pertanahan.

Perjanjian Pengikatan Jual Beli kemudian selanjutnya akan disingkat PPJB dibuat secara otentik atau dibuat dihadapan notaris sebagai pejabat umum, namun juga dapat dibuat dalam bentuk bawah tangan. Alasan para pihak tidak langsung minta dibuatkan akta jual beli untuk selanjutnya akan disingkat AJB untuk melanjutkan proses administrasi lainnya seperti mendaftarkan peralihan hak atas tanahnya, dikarenakan masih terdapat beberapa persyaratan diantaranya (1) pembayaran sebagai konsekuensi jual beli belum bisa terlaksana dengan penuh atau lunas, (2) surat-surat atau dokumen para pihak belum lengkap, dan (3) obyek atau bidang tanah masih dalam proses splitsing.

Perjanjian Pengikatan Jual Beli kemudian selanjutnya akan disingkat PPJB merupakan sebuah perjanjian yang dibuat berdasarkan kesepakatan, guna mengatur kepentingan para pihak. Sedangkan pengertian perjanjian pengikatan jual beli menurut Herlien Budiono, yaitu perjanjian bantuan yang berfungsi sebagai perjanjian pendahuluan yang bentuknya bebas, sehingga PPJB ini dapat dikategorikan ke dalam perjanjian pendahuluan yang dibuat sebelum dilaksanakannya perjanjian utama/pokok. ${ }^{8}$ Dibuatnya PPJB akan memberikan kepastian hukum bagi para pihak serta dapat meminimalisir terjadinya sengketa, mengingat membuat akta otentik

8 Dewi Kurnia Putri, Amin Purnawan. (2017). Perbedaan Perjanjian Pengikatan Jual Beli Lunas Dengan Perjanjian Pengikatan Jual Beli Tidak Lunas, ISSN: 2581-2114, Jurnal Akta Vol. 4 No. 4, Fakultas Hukum Universitas Islam Sultan Agung, Semarang, hlm 12. 
tersebut merupakan kewenangan notaris sepanjang tidak melanggar undang-undang, agama dan kesusilaan. Berdasarkan pendapat Herlien Budiono tersebut, disimpulkan bahwa dibuatnya perjanjian pengikatan jual beli sebagai perjanjian pendahuluan yang bertujuan ketika dalam proses PPJB masih belum terpenuhinya syarat-syarat yang menjadi kewajiban bagi pihak penjual dan pihak pembeli, maka notaris berhak menunda pembuatan akta jual beli sebagai perjanjian pokok dari jual belinya. Sehingga kepentingan para pihak dapat terlindungi.

Akta PPJB dan kuasa menjual yang dibuat dalam akta tersendiri maupun menjadi satu kesatuan terjadi dikarenakan satu dan lain hal sebagai contohnya adalah ketika obyek jual beli tersebut dijadikan komoditi dagangan atau investasi, kemudian datang kepada notaris dengan membawa kuasa menjual yang mutlak tanpa menunjukkan PPJB tersebut.Akta kuasa menjual tadi digunakan sebagai kuasa untuk mengalihkan atau memindah tangankan hak atas tanah, oleh notaris dibuatkan lagi PPJB dan kuasa menjual dan seterusnya, sehingga PPJB dan kuasa menjual tersebut digunakan berulang kali. Berdasarkan keadaan tersebut diatas yang tidak pernah ditunjukkan kepada notaris atau mungkin sudah ditunjukkan akan tetapi tetap dibuat PPJB dan kuasa menjual berulang-ulang, maka saat dibuat akta jual beli oleh PPAT sesuai letak obyek tanah yang bersangkutan terjadi kesulitan pada saat pendaftaran hak di Kantor Pertanahan. Hal demikian terjadi karena kurang telitinya notaris yang membuatkan akta tersebut sehingga tidak menjalankan Pasal 16 ayat (1) huruf a Undang-Undang Nomor 2 tahun 2014 atas perubahan atas Undang-Undang Nomor 30 Tahun 2004 tentang Jabatan Notaris dan penyimpangan teknis yang dilakukan oleh pihak penjual terkait dengan putusnya riwayat tanah atas obyek hak atas tanah yang statusnya masih dalam permohonan hak milik dijadikan obyek jual beli.

Pembuatan PPJB dalam prakteknya terdapat penggunan PPJB dengan kuasa menjual, ada pula hanya dibuat PPJB saja.Penggunaan PPJB tanpa diikuti kuasa menjual tersendiri, dapat diartikan PPJB tersebut juga menyebutkan kuasa menjual di dalam klausulanya. Perlu diketahui bahwa dalam kuasa menjual masuk kedalam kategori kuasa yang digunakan untuk memindahtangankan benda yang sejatinya hanya dapat dilakukan oleh pemiliknya saja, maka dari itu, dalam kuasa menjual tersebut diperlukan suatu pemberian kuasa dengan kata-kata yang tegas di dalam aktanya (Pasal 1796 KUH Perdata). PPJB lebih dari satu atau sering disebut PPJB bertingkat terjadi karena seringkali proses pengikatan jual beli sebelumnya tidak ditunjukkan oleh pihak penjualnya kepada notaris, sebatas menunjukkan kuasa menjualnya saja, sedangkan kuasa menjual mutlak tidak bisa berdiri sendiri, harus didahului dengan adanya PPJB.

PPJB bertingkat terjadi karena kesalahan ada pada notaris, ketika pihak penjual hanya memberikan kuasa menjual maka notaris pasti harus jeli, ketika kuasa menjual tersebut berisi mutlak, pasti terdapat pula akta PPJB, jika kuasa menjual tersebut berdiri sendiri berarti melanggar Pasal 1813 KUHPerdata, kalaupun lolos berarti kesalahan dari notarisnya, maka dari itu notaris harus amanah dengan memegang teguh berpedoman pada Pasal 16 ayat 1 UUJN. Berdiri sendiri seharusnya notaris menolak, karena apabila pihak penjual yang namanya masih tercantum dalam sertifikat kemudian melakukan pembuatan PPJB bertingkat, disetiap peralihannya pasti juga terhutang pajak pajak penghasilan yang dalam prakteknya sering dijumpai pajak penghasilannya belum terbayarkan.

Sejak instruksi Mendagri No. 14 tahun 1982 berlaku, penggunaan kuasa mutlak sudah dilarang. Penggunaan kuasa mutlak juga ditemui dalam PP 24 tahun 1997 tentang Pendafataran Tanah. Namun dalam praktek notaris sampai saat ini diketahui bahwa penggunaan kuasa mutlak dalam PPJB merupakan hal yang masih sering ditemukan. Hal inilah yang sering menimbulkan konflik di kemudian hari, 
karena penggunaan kuasa mutlak bertentangan dengan peraturan perundangundangan yang berlaku di indonesia.Konflik yang terjadi antara para pihak ini juga dapat menimbulkan kerugian bagi notaris yang dipersalahkan atas perjanjian yang dibuat oleh para pihak, sehingga perlu diketahui sampai sejauh mana keabsahan dari penggunaan kuasa mutlak dalam PPJB tanah dan apa akibat hukum dari PPJB tanah yang menggunakan kuasa mutlak. Perjanjian Pengikatan Jual Beli digunakan sebagai media guna mengakomodasi kepentingan para pihak penjual dan pembeli, namun dibalik pembuatan PPJB praktiknya juga memiliki banyak permasalahan terjadi.

Berdasarkan uraian dan permasalahan di atas, permasalahan yang dikaji adalah pertama : bagaimana perlindungan hukum bagi pembeli hak atas tanah yang terakhir jika pemindahan haknya ditolak oleh Kantor Pertanahan Kota Malang berdasarkan Pasal 39 ayat (1) huruf d Peraturan Pemerintah Nomor 24 Tahun 1997? kedua : bagaimana tanggung jawab notaris berdasarkan Pasal 16 ayat (1) huruf a Undang-Undang Nomor 2 Tahun 2014 atas perubahan Undang-Undang Nomor 30 Tahun 2004 tentang Jabatan Notaris dalam hal pembuatan akta PPJB dan kuasa menjual yang mengakibatkan kerugian bagi pihak pembeli hak atas tanah tersebut?

\section{PEMBAHASAN}

Perlindungan hukum bagi pembeli hak atas tanah yang terakhir jika pemindahan haknya ditolak oleh Kantor Pertanahan Kota Malang berdasarkan Pasal 39 ayat (1) huruf d Peraturan Pemerintah Nomor 24 Tahun 1997 tentang Pendaftaran Tanah

Lahirnya Perjanjian Jual Beli menekankan arti pentingnya kapan pihak penjual dan pembeli menjadi saling terikat karenanya. Pihak penjual dan pembeli saling terikat karena adanya kesepakatan bertukar kewajiban antar para pihak yang nantinya ketika kewajiban tersebut terpenuhi, akan melahirkan hak yang diinginkan para kontraktan yang memang sejak semula sudah dijadikan pemantik untuk melakukan hubungan hukum. ${ }^{9}$ Sesuai hakikatnya, kelahiran Perjanjian Jual Beli, tak lain merupakan bingkai hukum yang mewadahi para pihak beserta dengan segala aktivitas bisnis yang dikelolanya, agar dengan model tersebut bisnis yang bersangkutan dapat memperoleh kepastian posisi hukumnya.

Definisi dari Pasal 1457 KUHPerdata menyinggung tentang sepakatnya para pihak terhadap benda tertentu dengan sejumlah harga yang sudah dipastikan, menyunggingkan corak bahwa Perjanjian Jual Beli tergolong sebagai Perjanjian Konsensuil. Bahwa dengan sepakat tentang benda dan harga selaku unsur esensialnya, maka terbentuklah sebuah perjanjian di antara para pihak yang kemudian bermuara pada lahirnya perikatan sebagaimana dituntut oleh Pasal 1233 KUHPerdata. ${ }^{10}$

Buku III Kitab Undang-Undang Hukum Perdata, syarat-syarat untuk terjadinya perjanjian jual beli, ketika pihak penjual dan pihak pembeli telah mencapai persetujuan tentang barang dan harganya. Secara khusus terkait dengan perjanjian yang bersifat jual beli saat inim Pasal 1458 dan Pasal 1459 KUHPerdata mengantur bahwa jual beli dianggap telah terjadi antara pihak penjual dan pihak pembeli, seketika setelah para pihak mencapai kata sepakat tentang benda dan harganya, meskipun benda tersebut belum diserahkan, maupun harganya belum dibayar. Akan tetapi hak milik atas tanah yang dijual tidaklah berpindah kepada pihak pembeli, selama penyerahannya belum dilakukan menurut hukum. Sehingga hak milik yang diperjual belikan baru dianggap beralih/berpindah kepada pihak pembeli setelah dilakukan penyerahan atas barang tersebut dari pihak penjual kepada pihak pembeli.

Perjanjian pengikatan jual beli merupakan perjanjian obligator, dengan kata lain perjanjian tersebut pada asasnya baru

\footnotetext{
${ }^{9}$ Isnaeni, Moch. Isnaeni, Pengantar Hukum Jaminan Kebendaan, Surabaya, PT. Revka Petra Media, 2016, hlm. 33.

10 ibid, hlm. 29.
} 
akan melahirkan perikatan awal. Hak atas obyek perjanjian belum beralih, untuk terjadinya peralihan masih diperlukan adanya levering (penyerahan), dengan tujuan untuk mengalihkan hak milik dari benda tersebut. Perjanjian pengikatan jual beli tidak serta merta menyebabkan terjadinya peralihan hak atas tanah dari pihak penjual kepada pihak pembeli sebelum dilakukan penyerahan (levering).

Berdasarkan hal tersebut maka hak milik atas barang yang dijual tidak pindah kepada pembeli selama barang itu belum diserahkan menurut Pasal 612, 613, dan 616 KUHPerdata. Menurut KUHPerdata perjanjian jual beli saja belum mengakibatkan beralihnya hak milik dari penjual kepada pembeli, untuk beralihnya hak atas tanah yang diperjual belikan masih diperlukan lembaga lain yakni penyerahan (levering).

Peralihan hak atas tanah merupakan perbuatan hukum pemindahan hak atas tanah yang dilakukan dengan sengaja agar hak tersebut beralih dari pemegang hak semula dan kemudian menjadi hak pihak lain. ${ }^{11}$ Pendaftaran tanah merupakan hal yang penting sebagai bukti hak yang kuat terhadap hak atas tanah untuk membuktikan sebagai pemilik hak atas tanah secara sah, ${ }^{12}$ kemudian dengan pencatatan adanya pemindahan hak atas tanah dalam buku tanah dan sertifikat maka penerima hak mempunyai alat bukti yang kuat atas tanah yang diperolehnya. ${ }^{13}$

Perjanjian pengikatan jual beli yang berkaitan dengan pengalihan hak atas tanah yang dibuat di hadapan Notaris, yang menjadi larangan dalam pembuatan PPJB berkenaan dengan hak-hak atas tanah yang berasal dari Hukum Adat dikaitkan dengan Pasal 2 ayat (1) ketentuan konversi UUPA, maka hak milik Yasan, Andarbeni, Hak atas Druwe desa, Pesini secara hukum

\footnotetext{
${ }^{11}$ K. Wantjik Saleh, Hak Anda Atas Tanah, Jakarta, Ghalia Indonesia, 1977, hlm. 15-18.

12 Adrian Sutedi, Peralihan Hak Atas Tanah dan Pendaftarannya, Jakarta, Sinar Grafika, 2018, hlm. 125.

${ }^{13}$ Pasal 23 ayat (2) Undang-Undang Pokok Agraria.
}

dikonversi menjadi Hak Milik. Terhadap tanah-tanah tersebut menurut ketentuan Pasal 19 UUPA jo. Peraturan Pemerintah No. 24 Tahun 1997 tentang pendaftaran tanah, harus didaftarkan namun sebagian besar masih belum didaftarkan. Bagi tanah yang sudah didaftarkan memang tidak banyak mengalami hambatan dalam hal adanya peralihan hak atas tanah tersebut, akan tetapi, untuk tanah yang belum didaftar akan ditemukan banyak hambatan dalam hal adanya peralihan hak atas tanah tersebut. ${ }^{14}$

Hambatan peralihan hak atas tanah dengan menggunakan PPJB adalah ketika tanah yang belum didaftar mengalami putusnya riwayat tanah sejak tahun 1960 hingga saat terakhir kali dimiliki oleh pemegang haknya, ${ }^{15}$ hal yang demikian dapat mengakibatkan kerugian bagi pihak pembeli apabila tetap dibuatkan akta perjanjian pengikatan jual beli, berdasarkan hal tersebut menurut penulis ketika perjanjian pengikatan jual beli dengan dasar hak atas tanah yang belum terdaftar dilarang pembuatannya, karena pihak pembeli tidak mendapatkan perlindungan hukum.

Pendaftaran tanah ini dikenal dengan Recht Kadaster, ketentuan pendaftaran tanah di Indonesia diatur dalam UUPA Pasal 19, yang dilaksanakan dengan Peraturan Pemerintah No. 10 Tahun 1961 dan kemudian diganti dengan Peraturan Pemerintah No. 24 Tahun 1997 yang berlaku efektif sejak tanggal 8 Oktober 1997. Peraturan pemerintah ini merupakan bentuk pelaksanaan Pendaftaran Tanah dalam rangka Recht Kadaster yang bertujuan memberikan kepastian hukum dan perlindungan hukum kepada pemegang hak atas tanah.

Sejak berlakunya PP No. 10 Tahun 1961 tentang Pendaftaran Tanah, jual beli dilakukan oleh para pihak dihadapan PPAT yang bertugas membuat aktanya. Dengan dilakukannya jual beli di hadapan PPAT, dipenuhi syarat terang (bukan perbuatan hukum yang gelap, yang dilakukan secara

\footnotetext{
${ }^{14}$ Op.Cit, hlm. 2.

15 Nanang Dwi Winarko, sesi wawancara, pada tanggal 23 Maret 2020.
} 
sembunyi-sembunyi). Akta jual beli yang ditandatangani para pihak membuktikan telah terjadi pemindahan hak dari penjual kepada pembelinya dengan disertai pembayaran harganya, telah memenuhi syarat tunai dan menunjukkan bahwa secara nyata atau riil perbuatan hukum jual beli yang bersangkutan telah dilaksanakan.

Salah satu aspek yang penting di dalam hukum tanah adalah tentang hubungan hukum antara tanah dengan benda lain yang melekat padanya. Kepastian hukum akan kedudukan hukum dari benda yang melekat pada tanah itu sangat penting karena hal ini mempunyai pengaruh yang luas terhadap segala hubungan hukum yang menyangkut tanah dan benda yang melekat padanya. Di dalam hukum tanah dikenal ada 2 (dua) asas yang satu sama lain bertentangan yaitu yang dikenal dengan asas pelekatan Vertikal (verticale accessie beginsel) dan asas pemisahan horizontal (horizontale scheiding beginsel).

Sejak berlakunya KUH Perdata kedua asas ini diterapkan secara berdampingan sesuai dengan tata hukum yang berlaku dewasa ini (masih dualistis). Sejak berlakunya UUPA maka ketentuan Buku III KUH Perdata sepanjang mengenai bumi, air serta kekayaan di dalamnya telah dicabut, kecuali tentang hipotik. Asas pelekatan vertikal yaitu asas yang merdasarkan pemilikan tanah dan segala benda yang melekat padanya sebagai suatu kesatuan yang tertancap menjadi satu. Dalam hukum tanah negara-negara yang menggunakan apa yang disebut Asas Accessie atau Asas Pelekatan, bangunan dan tanaman yang ada di atas dan merupakan satu kesatuan dengan tanah, merupakan bagian dari tanah yang bersangkutan. ${ }^{16}$ Sehingga disimpulkan bahwa tanah dan bangunan atau segala sesuatu yang berdiri di atas tanah menjadi satu kesatuan.

16 Cicilia Putri Andari, Djumadi Purwoatmodjo. Akibat Hukum Asas

Pemisahan Horizontal Dalam Peralihan Hak Atas Tanah. (2019). ISSN: 2086-1702, Notarius, No. 2, Volume 12, Fakultas Hukum Universitas Diponegoro, Semarang, hlm. 709. $\begin{array}{rcr}\text { Dalam } & \text { hukum } & \text { Indonesia } \\ \text { dimungkinkan } & \text { pemilikan secara pribadi }\end{array}$ bagian-bagian bangunan, karena hukum Indonesia menggunakan asas pemisahan horizontal, yaitu asas hukum adat yang merupakan dasar Hukum Tanah Nasional. Berdasarkan asas pemisahan horizontal pemilikan atas tanah dan benda-benda yang berada di atas tanah itu adalah terpisah. Pemilikan atas tanah terlepas dari bendabenda yang ada di atas tanah, sehingga pemilik hak atas tanah dan pemilik atas bangunan yang berada di atasnya dapat berbeda. Sehingga disimpulkan bahwa pemilik bangunan belum tentu sebagai pemilik hak atas tanah.

Undang-Undang Nomor 5 Tahun 1960 tentang Peraturan Dasar Pokok-Pokok Agraria (selanjutnya disebut UUPA) merupakan perwujudan upaya maksimal bangsa Indonesia untuk membebaskan diri dari ketergantungan dengan bangsa lain di bidang hukum pertanahan. Sebelum berlakunya UUPA, Indonesia menganut 2 (dua) hukum tanah yang berbeda, yakni : Hukum Tanah Kolonial yang dituangkan dalam Burgelijk Wetboek (selanjutnya disebut dengan BW) dan Hukum Tanah Adat yang bersumber dari hukum adat. Terdapat perbedaan yang signifikan di antara kedua hukum tersebut, dimana hukum tanah kolonial yang bersumber pada BW menganut asas perlekatan atau yang disebut juga sebagai asas natrekking accessie. Asas perlekatan ini secara tegas dinyatakan dalam BW khususnya pada pasal 500, Pasal 571, dan Pasal 601 yang menyatakan bahwa hak milik atas sebidang tanah mengandung pula kepemilikan atas segala sesuatu yang ada di atas tanah maupun di dalam tanah tersebut. Asas perlekatan yang dianut hukum tanah kolonial sangat bertentangan dengan filosofi Pancasila dimana hukum adat menganut asas pemisahan horizontal, dimana asas pemisahan horizontal yang dianut hukum adat menyatakan bahwa bangunan, tanaman dan benda-benda yang bersifat ekonomis lainnya yang ada di atas tanah bukanlah merupakan bagian tanah. 
Demi mewujudkan unifikasi hukum, peraturan dan keputusan agraria kolonial dicabut dan dibentuklah kesatuan hukum tanah nasional yang sesuai dengan kepribadian dan persatuan Indonesia sehingga dengan demikian tidak ada lagi penggolongan hukum tanah kolonial dan hukum tanah adat. Akan tetapi kesatuan Hukum Pertanahan Nasional dibentuk dengan didasari oleh Hukum Tanah Adat yang telah berlaku sebelumnya, karena hukum tanah adat tersebut telah dianut oleh sebagian besar rakyat Indonesia. ${ }^{17}$

Asas pemisahan horizontal adalah asas hukum pertanahan yang diatur dalam hukum adat. Berdasarkan asas pemisahan horizontal maka tanah terlepas dari segala benda yang melekat padanya. Asas pemisahan horizontal hak-hak atas tanah yang merupakan sifat asli hak-hak dalam hukum adat tetap dipertahankan tetapi disesuaikan dengan kenyataan kebutuhan masyarakat masa kini. Hak atas tanah tidak meliputi pemilikan atas bangunan yang ada di atasnya. Bangunan, tanaman dan bendabenda lain yang ada di atas suatu bidang tanah adalah milik pihak yang membangun atau menanam, baik pihak itu pemegang hak atas tanahnya sendiri atau bukan, kecuali kalau ada perjanjian sebaliknya. Sehingga perbuatan hukum mengenai tanah tidak dengan sendirinya meliputi bangunan, tanaman dan/atau benda-benda lain yang ada di atasnya, kalau hal itu tidak secara tegas dinyatakan. ${ }^{18}$

Perjanjian Pengikatan Jual Beli untuk selanjutnya disebut PPJB merupakan perjanjian pendahuluan sebelum dilakukannya penandatanganan Akta Jual Beli dihadapan Pejabat Pembuat Akta Tanah, keberadaan PPJB telah diatur dalam Undang-Undang No. 1 Tahun 2011 tentang Perumahan dan Permukiman (sebagai lex specialis). Kitab Undang-Undang Hukum Perdata tidak mengatur perjanjian pengikatan jual beli, akan tetapi bila berpedoman dengan unsur-unsur sebuah

\footnotetext{
17 Urip Santoso, Hukum Agraria: Kajian Komprehensif, Kencana, 2012, hlm. 67.

${ }^{18}$ Boedi Harsono, Op.Cit, hlm. 25
}

perjanjian dan dengan adanya kesepakatan antara para pihak dalam perjanjian tersebut maka Perjanjian Pengikatan Jual Beli yang merupakan perjanjian pendahuluan tersebut juga tunduk pada Buku Ke III Kitab Undang-Undang Hukum Perdata.

Perjanjian pengikatan jual beli dapat digunakan untuk objek perjanjian berupa benda tidak bergerak, sebagai contohnya adalah tanah dan bangunan yang sertifikat hak atas tanahnya masih dalam proses splitsing di Kantor Pertanahan. Berdasarkan hal tersebut kemudian Perjanjian Pengikatan Jual Beli tunduk pada hukum perikatan karena dengan adanya kesepakatan yang dibuat oleh pihak penjual dan pihak pembeli (Pasal 1320 butir 1 (pertama) Jo. Pasal 1338 butir 1 (pertama) Kitab Undang-Undang Hukum Perdata), sehingga ketentuan dalam Perjanjian Pengikatan Jual Beli tersebut akan dituangkan dalam perjanjian pokok.

Akta Perjanjian Pengikatan Jual Beli dalam peralihan hak atas tanah sebagai akta otentik berlaku ketika akta tersebut dibuat dihadapan dan ditandatangani di hadapan Notaris, sehingga Notaris sah membuat akta Perjanjian Pengikatan Jual Beli. Akta Perjanjian Pengikatan Jual Beli sebagai dasar untuk dibuatnya Akta Jual Beli dihadapan Pejabat Pembuat Akta Tanah, kemudian dapat dilakukan pendaftaran di Kantor Pertanahan. Landasan hukum Notaris dalam membuat Perjanjian Pengikatan Jual Beli terdapat dalam ketentuan Pasal 15 ayat 2 huruf f UndangUndang No. 2 Tahun 2014 tentang Perubahan Atas Undang-Undang No. 30 Tahun 2004 tentang Jabatan Notaris mengenai kewenangan Notaris membuat akta yang berkaitan dengan pertanahan, namun dengan dasar Perjanjian Pengikatan Jual Beli belum dapat menjadikan beralihnya hak atas tanah kepada pihak pembeli.

Dalam rangka melindungi kepentingan para pihak dalam Perjanjian Pengikatan Jual Beli ini perlu adanya "kerangka dasar" dalam klausula yang dibuat oleh Notaris sebagai pejabat umum yang berwenang membuat akta otentik yaitu 
dengan mengamankan kepentingan para pihak dengan beberapa point, yaitu :

\section{Klausula Perjanjian}

Pembuatan Perjanjian Pengikatan Jual beli terdapat pembayaran lunas dan tidak lunas, apabila terjadi pembayaran secara tidak lunas maka klausula perjanjian yang perlu ditekankan dalam akta adalah Sertifikat Hak atas Tanah harus berada di Pihak Notaris, mengingat Notaris dalam menjalankan jabatannya wajib bertindak tidak memihak dan menjaga kepentingan pihak yang terkait dalam perbuatan hukum hingga pembayaran tersebut lunas.

Perlu diketahui pula terkait kejelasan pembayaran, apakah pembayarannya dilakukan secara bertahap sesuai dengan kesepakatan para pihak.

\section{Jangka Waktu Pembayaran}

Dalam membuat kesepakatan diantara pihak penjual dan pihak pembeli pasti terdapat metode pembayaran secara tidak lunas ataukah secara lunas. Akan tetapi, pembayaran yang dilakukan secara tidak lunas seringkali merugikan pihak penjual. Sehingga perlunya dituangkan dalam klausula terkait dengan penegasan sampai batas kapan pembayaran yang dilakukan pihak pembeli dapat dipenuhi prestasinya, hal tersebut dilakukan oleh Notaris sebagai bentuk penegasan kepada pihak pembeli agar tidak mengabaikan prestasinya yang perlu dipenuhi kepada pihak penjual.

\section{Sanksi}

Notaris dalam jabatannya sebagai pihak yang netral bertugas untuk mengakomodasi kepentingan pihak penjual dan pihak pembeli dengan memberikan klausula sanksi kepada pihak pembeli apabila didalam pelaksanaan pembayarannya terjadi keterlambatan, hal tersebut dilakukan guna menguatkan kedudukan pihak penjual agar pihak pembeli memiliki tanggung jawab dan terdapat tantangan bagi pihak pembeli agar dapat melaksanakan prestasi.

Keabsahan Hak Atas Tanah dan
Bangunan

Penandatanganan Perjanjian

Pengikatan Jual Beli dapat dilaksanakan setelah sertifikat hak atas tanah dan bangunan yang akan dijadikan obyek jual beli tersebut telah dilakukan "Cek Bersih" atau Pengecekan Sertifikat di Kantor Pertanahan dimana obyek hak atas tanah tersebut berada, hal tersebut sebagai langkah perlindungan hukum dari Notaris kepada para pihak agar perjanjian pengikatan Jual Beli tersebut dapat terlaksana.

Bagaimana Tanggung Jawab Notaris Berdasarkan Pasal 16 ayat (1) huruf a Undang-Undang Nomor 2 Tahun 2014 tentang Perubahan atas Undang-Undang Nomor 30 Tahun 2004 tentang Jabatan Notaris Dalam Hal Pembuatan Akta Perjanjian Pengikatan Jual Beli dan Kuasa Menjual Yang Mengakibatkan Kerugian Bagi Pihak Pembeli Hak Atas Tanah Tersebut?

Akta otentik memiliki 2 (dua) fungsi yaitu akta sebagai fungsi formal yang mempunyai arti bahwa suatu perbuatan hukum akan menjadi lebih lengkap apabila dibuat suatu akta. Fungsi alat bukti yaitu akta sebagai alat pembuktian dimana dibuatnya akta tersebut oleh para pihak yang terikat dalam suatu perjanjian di tujukan untuk pembuktian di kemudian hari, hal tersebut tercermin dengan dibuatnya akta Perjanjian Pengikatan Jual Beli sebagai perjanjian pendahuluan karena hak atas tanah yang akan dijadikan obyek jual beli masih dalam proses.

Berdasarkan penjelasan di atas Peralihan hak atas tanah terjadi karena kebutuhan diantara para pihak, tidak dipungkiri ketika pihak penjual melakukan peralihan hak atas tanah miliknya kepada pihak pembeli dikarenakan ingin menjadikan hak atas tanah tersebut sebagai komoditi atau investasi sehingga tidak didaftarkan peralihan haknya. Akan tetapi, pihak penjual hanya membuat peralihannya menggunakan akta Perjanjian Pengikatan Jual Beli dan Kuasa Menjual dan kemudian menunggu datangnya pembeli hak atas tanah yang baru. Hal tersebut dilakukan pihak penjual karena mengetahui bahwa 
riwayat tanah hak atas tanah tersebut terputus, akan tetapi tidak menyampaikan kepada pihak pembeli. Berdasarkan hal tersebut dalam artikel ini mengakibatkan pihak pembeli hak atas tanah yang terakhir tidak mendapatkan perlindungan hukum.

Sebagaimana diatur dalam Pasal 16 ayat (1) huruf a, Notaris dalam menjalankan jabatannya wajib bertindak menjaga kepentingan para pihak yang terkait dalam perbuatan hukum. Disamping itu, wajib mengutamakan adanya keseimbangan antara hak dan kewajiban para pihak. Notaris dituntut senantiasa mendengar dan mempertimbangkan keinginan para pihak, sehingga kepentingan para pihak tersampaikan melalui akta perjanjian pengaikatan jual beli yang dibuat oleh Notaris.

Perjanjian pengikatan jual beli yang dibuat seharusnya mengutamakan kejelasan obyek hak atas tanahnya, akan tetapi ketika terjadi permasalahan yang dibahas dalam peneliti ini, pihak pembeli hak atas tanah yang terakhir mengalami kesulitan ketika mendaftarkan peralihan hak atas tanahnya di kantor pertanahan kota malang.

Berdasarkan permasalahan yang dibahas dalam artikel ini dengan merujuk Pasal 39 ayat 1 huruf d Peraturan Pemerintah Nomor 24 Tahun 1997 tentang Pendaftaran Tanah, maka: Notaris wajib melihat dengan cermat ketika terdapat Perjanjian Pengikatan Jual Beli yang dibuat secara bertingkat yang di ikuti dengan Kuasa Menjual, kedudukan Kuasa Menjual tersebut apakah murni sebagai Kuasa Menjual ataukah terdapat unsur peralihan di dalamnya dan Notaris sebelum membuat akta Perjanjian Pengikatan Jual Beli harus memperhatikan apakah hak atas tanah yang belum terdaftar sebagai hak milik berdasarkan Pasal 16 ayat (1) UndangUndang Nomor 5 Tahun 1960 tentang Peraturan Dasar Pokok-Pokok Agraria tesebut riwayut tanahnya sesuai dengan kutipan Letter $\mathrm{C}$ yang ada dalam Buku Register Kantor Desa/Kelurahan dimana hak atas tanah tersebut berada.

\section{Diagram Alir}
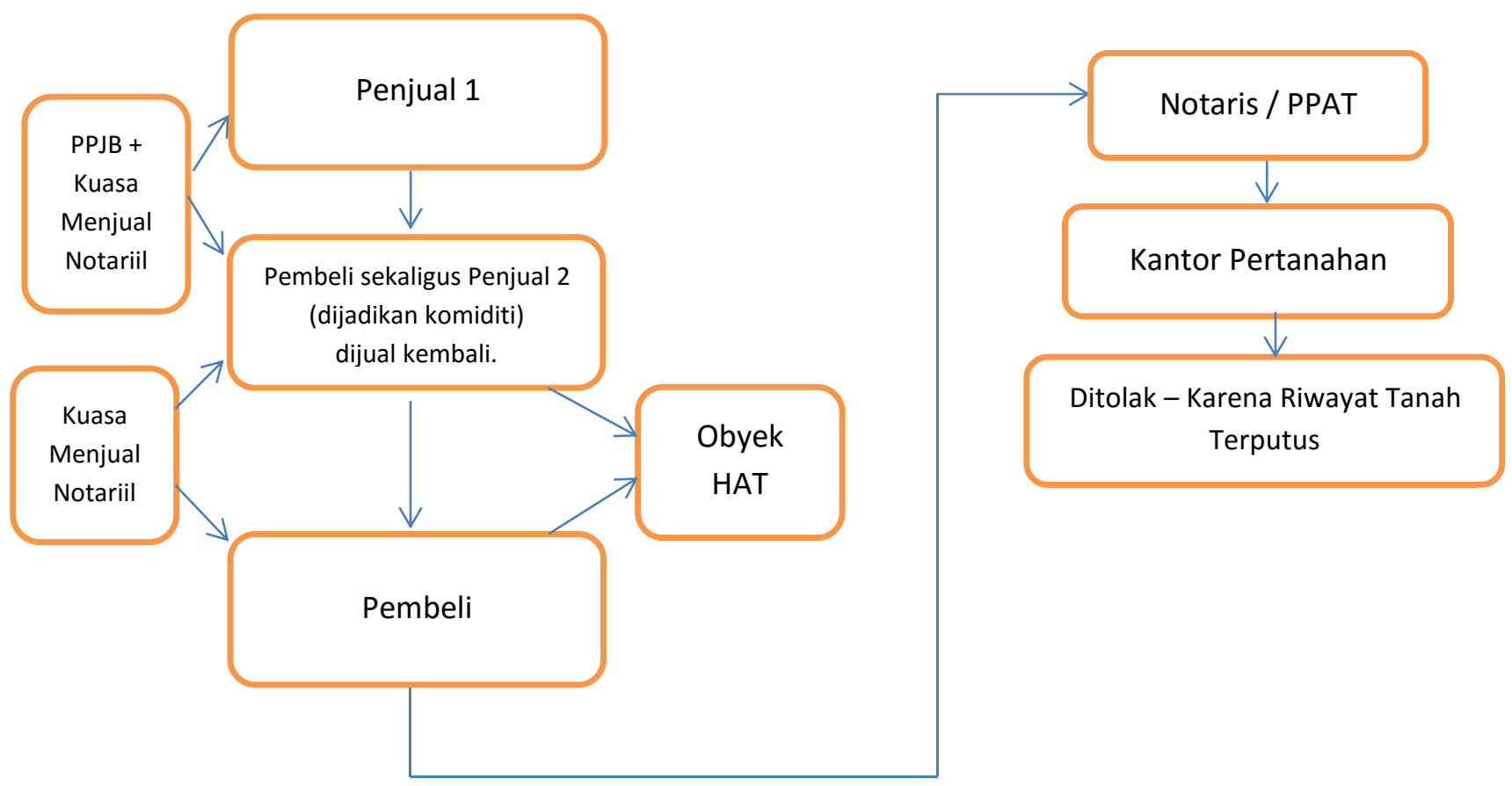


\section{Perspektif Prinsip-Prinsip Ekonomi Syariah}

Di dalam hukum ekonomi syariah, di antara tujuan jual beli adalah untuk mencapai kesejahteraan antara pembeli dan penjual dimana tidak boleh dalam jual beli ada pihak yang dirugikan. Perjanjian pengikatan jual beli sebagaimana yang dijelaskan di atas dalam hukum Islam termasuk dalam kategori perjanjian yang tidah shahih. Suatu akad dikatakan tidak shahih ketika di dalam akad tersebut terdapat kekurangan pada rukun atau syaratsyaratnya, sehingga seluruh akibat hukum akad itu tidak berlaku dan tidak mengikat pihak-pihak yang berakad.

Menurut para ulama dari kalangan Hanafiyah dan Malikiyah, akad yang tidak shahih dapat dibagi menjadi dua macam, yakni: (1) Akad Bathil. Akad bathil adalah akad yang tidak memenuhi salah satu rukunnya atau ada larangan langsung dari syara'. Misalnya, objek jual beli itu tidak jelas, atau terdapat unsur penipuan, seperti menjual ikan dalam lautan, atau salah satu pihak yang berakad tidak cakap dalam bertindak hukum. (2) Akad Fasid. Akad fasid adalah akad yang pada dasarnya disyari'atkan, akan tetapi sifat yang diakadkan itu tidak jelas. Misalnya, menjual rumah atau kendaraan yang tidak di tunjukkan tipe, jenis, dan bentuk rumah yang akan dijual, atau tidak disebut brand kendaraan yang dijual, sehingga menimbulkan perselisihan antara penjual dan pembeli. Ulama fiqh menyatakan bahwa akad bathil dan akad fasid mengandung esensi yang sama, yaitu tidak sah dan akad itu tidak mengakibatkan hukum apapun.

Di dalam transaksi ekonomi dalam Islam terdapat prinsip-prinsip yang harus dipatuhi dan dijadikan landasan dalam aktifitas ekonomi yang meliputi prinsip tauhid, prinsip keadilan, prinsip ta'awun, prinsip khilafah, serta prinsip maslahah. Dalam konteks ini,penulis hendak melihat masalah perjanjian pengikatan jual beli yang dibuat secara bertingkat dari perspektif prinsip kemaslahatan.
Ajaran syari'ah Islam secara umum memiliki tujuan pokok yang hendak diwujudkan melalui perintah-perintah dan جلب المصالح و دفع larngan-larangannya, yakni (mencapai kemaslahatan dan mencegah kerusakan). Izz al-Dîn Abd alSalâm berpendapat bahwa secara bahasa kata "maslahah" bermakna "manfaat". 19 Menurut Abu Hamid al-Ghazâlî, maslahah adalah usaha yang berorientasi pada pemeliharaan maksud-maksud syarî'ah, karena itu, semua perbuatan yang ditujukan untuk memelihara maksud-maksud syariah dinamakan sebagai maslahah, dan semua perbuatan yang menyebabkan rusaknya dan bahkan hilangnya eksistensinya disebut sebagai mafsadah. Sehingga mencegah terjadinya mafsadah berarti melakukan maslahah, karena perbuatan tersebut dapat menghasilkan maslahah. ${ }^{20}$ Demikian pula pandangan Najmuddin al-Thûfî, bahwa maslahah dimaknai sebagai jalan yang mengarah kepada terwujudnya tujuan-tujuan syarî'ah dalam konteks ibadah dan muamalah. Al-Thûfî sebagaimana dijelaskan membagi maslahah ke dalam dua kelompok, yakni maslahah dalam bidang ibadah dan adat. Ibadah sebagai maslahah karena menurutnya ibadah dianggap sebagai perantara bagi manusia kepada maksudmaksud syari'ah. Sedangkan adat ('urf) sebagai maslahah karena dianggap dapat menciptakan kemanfaatan bagi kehidupan masyarakat. ${ }^{21}$

Ibn 'Âsyûr mendefinisikan maslahah sebagai suatu konsekwensi pada perbuatan yang mengakibatkan terwujudnya suatu kebaikan atau kemanfaatan, baik secara kolektif maupun individu. ${ }^{22}$ Menurutnya tujuan utama syari'ah Islam adalah untuk

\footnotetext{
${ }^{19}$ Izz al-Dîn Abd al-Salâm, Qawâ 'id al-Ahkâm, 6-14.

${ }^{20}$ Muhammad Abu Hamid al-Ghazali, Al-Musytasyfa, jilid 2, (Beirut: Dâr al-Kitâb al-Ilmiyyah, t.th.), 286287.

${ }^{21}$ Musthafa Zaid, Shar'hu al-Arba'in al-Nawawiyah: Mulhaq bi al-Risâlah al-Maslahah fî Tashrî' alIslâmî Najmuddîn al-Thûfî, (t.tp: Dâr ak-Fî kr alArâbî, t.th), 211.

22 Muhammad Thâhîr Ibn 'Âshûr, Maqâshid alSharî'ah al-Islâmiyyah, 65.
} 
mewujudkan pemeliharaan kehidupan dari kerusakan dan kehancuran, melalui doktrindoktrinnya syari'ah Islam diturunkan untuk mewujudkan maslahah dan menjauhkan mafsadah. Sehingga timbul keyakinan bahwa keseluruhan dari hukum syar'i selalu berorientasi pada tercapainya maslahah dan untuk menghilangkan mafsadah baik yang tampak atau yang tersembunyi. ${ }^{23}$

Dalam konteks hukum ekonomi syariah, yang dimaksud dengan prinsip maslahah dalam aktivitas bermuamalah adalah bahwa dalam suatu kegiatan ekonomi harus terdapat unsur kepatuhan syariah (halal) dan membawa kemanfaatan bagi semua pihak yang bermuamalah, serta tidak menimbulkan mudharat atau merugikan salah satu atau semua pihak yang melakukan transaksi ekonomi tersebut. Adapun indikator kemaslahatan dalam hukum ekonomi syariah adalah mendatangkan manfaat berupa kesejahteraan, kebahagiaan, keuntungan, kemudahan, meringankan, menghindarkan mudharat (kerusakan/kerugian, dan pemerasan), serta hal-hal yang menyulitkan.

Kembali kepada masalah perjanjian pengikatan jual beli yang dibuat secara bertingkat dimana perjanjian jual beli seperti itu dapat menimbulkan kerugian bagi pihak pembeli hak atas tanah yang terakhir, dikarenakan hak atas tanah yang dijadikan sebagai obyek perjanjian jual beli tidak dapat didaftarkan karena terputusnya riwayat tanahnya. Artinya, pembeli yang

\footnotetext{
${ }^{23}$ Ibn 'Âsyûr menyatakan bahwa pada hakekatnya jalan untuk mencapai kemaslahatan jauh lebih luas dan beragam sehingga dalam mewujudkannya seseorang tidak harus selalu bergantung dengan ketentuan nash. Karena menurutnya akal pikiran manusia yang sehat akan selalu dapat melihat dan mengidentifikasi suatu kemaslahatan. Namun ia mengakui bahwa syari'ah merupakan cara termudah untuk mengetahui dan menentukan maslahah. Adapun kemaslahatan yang tidak termaktub dalam syari'ah beserta doktrin-doktrinnya yang partikular secara otomatis diserahkan kepada akal untuk menentukannya. Ibid,75-87. Bandingkan dengan tulisan Zul Ikromi. Pendekatan Istislahi Dalam Ijtihad Abu Bakar al-Shiddiq. Jurnal Mazahib, Volume XVI, Nomor 1, Juni 2017, 52.
}

terakhir tidak dapat memiliki tanah tersebut secara sah menurut hukum karena tidak dapat mendaftarkan sertifikasi tanah atas namanya. Ini adalah bentuk jual beli yang menimbulkan kerugian sehingga dilarang menurut Islam.

Jual beli tersebut juga dapat menimbulkan kemudharatan bagi pembeli trakhir disebabkan status kepemilikan atas tanah yang ia beli tidak jelas dan tidak ada kepastian hukum yang dapat melindunginya. Padahaaal dalam hukum ekonomi syariah, segala transaksi ekonomi yang menimbulkan mudharat bagi salah satu pihak harus dilarang dan dikategorikan sebagai bentuk transaksi yang tidak sah menurut hukum Islam.

\section{Kesimpulan}

\begin{tabular}{llr}
\multicolumn{2}{c}{ Berdasarkan } & \multicolumn{2}{c}{ analisis } & dan \\
pembahasan di & atas, & artikel ini \\
menyimpulkan, & Pertama, & Perjanjian
\end{tabular} Pengikatan Jual Beli yang dibuat secara bertingkat dapat menimbulkan kerugian bagi pihak pembeli hak atas tanah yang terakhir dikarenakan hak atas tanah yang dijadikan obyek perjanjian jual beli tidak dapat didaftarkan karena terputusnya riwayat tanahnya, sehingga pihak pembeli tidak mendapatkan perlindungan hukum. Kedua, Notaris dalam hal pembuatan akta perjanjian pengikatan jual beli wajib berpedoman pada Pasal 16 ayat (1) UndangUndang Nomor 2 Tahun 2014 tentang Perubahan Atas Undang-Undang Nomor 30 Tahun 2004 tentang Jabatan Notaris, bahwa notaris wajib bertindak saksama, kaitannya dengan klausula akta Kuasa Menjual yang dibawa oleh pihak penjual apakah bertindak sebagai penerima kuasa murni atau kuasa menjual yang bersifat mutlak. Dalam perepektif prinsip hukum ekonomi syariah, perjanjian jual beli semacam itu termasuk dalam kategori perjanjian yang batil dan fasad, karena terdapat unsur yang merugikan salah satu pihak dan menimbulkan kemudharatan 


\section{.DAFTAR PUSTAKA}

\section{Artikel/Buku/Laporan}

Adrian Sutedi, Peralihan Hak Atas Tanah dan Pendaftarannya, Jakarta, Sinar Grafika, 2018

Boedi Harsono, Hukum Agraria Indonesia: Sejarah Pembentukan Undang-Undang Pokok Agraria, Isi dan Pelaksanaanya, Cetakan ke-7, Jakarta, Univ. Trisakti, 2013

Cicilia Putri Andari, Djumadi Purwoatmodjo. Akibat Hukum Asas

Pemisahan Horizontal Dalam Peralihan Hak Atas Tanah. (2019). ISSN: 2086-1702, Notarius, No. 2, Volume 12, Fakultas Hukum Universitas Diponegoro, Semarang.

Dewi Kurnia Putri, Amin Purnawan. (2017). Perbedaan Perjanjian Pengikatan Jual Beli

Lunas Dengan Perjanjian Pengikatan Jual Beli Tidak Lunas, ISSN: 2581-2114, Jurnal

Akta Vol. 4 No. 4, Fakultas Hukum Universitas Islam Sultan Agung, Semarang.

Herlien Budiono. Demikian Akta Ini, Bandung, PT. Citra Aditya Bakti. 2018.

K. Wantjik Saleh, Hak Anda Atas Tanah, Jakarta, Ghalia Indonesia, 1977

Nanang Dwi Winarko, Sesi Wawancara, 2020

Moch. Isnaeni, Pengantar Hukum Jaminan Kebendaan, Surabaya, PT. Revka Petra Media, 2016

Urip Santoso, Hukum Agraria: Kajian Komprehensif, Kencana, 2012

Widjaja Gunawan, Kartini Muljadi, Jual Beli, Jakarta: PT. Raja Grafindo Persada, 2003

\section{Peraturan dan Putusan Hukum}

Republik Indonesia. Undang-Undang Nomor 2 Tahun 2014 tentang Perubahan atas UndangUndang Nomor 30 Tahun 2004 tentang Jabatan Notaris.

Republik Indonesia. Undang-Undang No. 5 Tahun 1960 tentang Ketentuan Dasar PokokPokok Agraria.

Republik Indonesia, Undang-Undang Nomor 20 Tahun 2011 tentang Rumah Susun.

Republik Indonesia, Undang-Undang Nomor 1 Tahun 2011 tentang Perumahan dan Permukiman.

Peraturan Pemerintah Nomor 24 Tahun 1997 tentang Pendaftaran Tanah. 